\title{
Resilience and Streetism: The Experiences from the Field
}

\author{
Tushar Savarkar* \\ Researcher, Mumbai, India
}

Submission: August 17, 2018; Published: August 24, 2018

*Corresponding author: Tushar Savarkar, Researcher, Mumbai, India, Tel: 9892571353; Email: tusharsavarkar@gmail.com

\section{Opinion}

The 'street children' is a wage terminology, include the children living with street families, institutionalized children, child labour those who have regular or occasional contact with their families or relatives and then lastly, children living on the street are those who fend for themselves either because their families have abandoned them, or because they walked away finding the streets more welcoming than their homes. Many of them landed on street because of negative experiences, abuse, violence, and many other traumatic experiences. There is a number of studies that have addressed the vulnerabilities faced by these children while some of these studies further tried to correlate the factors like, abuse, sexual problems, violence with their mental health. But rarely any study might have shown why there is a different effect of all these factors on children though they are staying in the same environment. Previous research had observed that age, gender, socio-economic status, plays an important role in the development of their capacities to deal with the adversities [1].

Resilience is nothing but the capacities of an individual to overcome the stresses and adversities due to the marginality [2]. Other researchers define it as a positive adaptation capacity of an individual with his/ her adversities. Resilience is not the personal traits but a product of environment and its interaction between adverse environment and individual [3-5]. Another researcher added that resilience is a psychological process in which individual face the risks and threats and adversities but stay stable and have a good outcome [6]. Some studies argued that street children develop their capacities to tackle many days to day problems, risks, adversities, and threats. They use strategies like autonomy and control, group solidarity, problem solution and manipulation [7-9].

Despite living under extremely harsh circumstances, street children display resilience and utilize effective coping strategies in their struggle for survival. Children are thus agents of their own development and, even in situations of adversity, they can consciously act upon and influence the environments in which they live [10-11]. A comparative study of the street and non- street children and concludes that street children are flexible and adaptable to face traumatic events and adversities vis-a-vis to non-street children $[12,13]$.

The survey has carried on during the year 2015-16 to understand the various socio-economic, health and mental health issues of children living on street in Mumbai city. The study found that these children have a unique capacity and effective coping strategies in their struggle for survival [14]. The field experiences suggest that as children land up on street, they get the soft corner and sympathy from the peers as well as the society. Later in life, they started experiencing an increasing number of events of abuse and violence that adds to their vulnerability and distresses. After the certain stage, they are acquainted with the street life and found the lesser effect of the life events or negative experiences. One social worker who is currently working with an NGO and also spent many years on street during his childhood said that when child land up on street he or she may be surprised with the street realities. As the child has no or less option of survival he/ she has to adjust to the situation. At street life, almost all children had gone through this situation they have a sympathy with the new peer or friend.

The child receives a fair treatment but as he/ she accommodate with the environment, the peers especially the elders behaving differently. By that time, he or she also faced the events of abuse from peers or from people. Such events appreciably affect their mental status. But afterward, they become stable and able to cope up with this. Generally, as they reach their adulthood (18-20 years of life) they are much more able to react to the adversity. One boy shared his experiences in the same manner

«Sir when I first came here I was rather despondent. I failed to understand what was going on all around. At that very juncture, my friends who were here helped me a lot. I stayed along with them and got embroiled in these activities. But then I was subjected to physical assault, verbal abuse and a lot of bad things happened to me. Some of those who were in my gang were compelled by outsiders to get commit illegal activities. 
Whenever we are working on / staying on the streets or the station, we are been chased off and driven away by the police. Even we are dragooned into doing the police's illegal bidding. When I was new there was a lot of tension engulfing my mind, could not sleep properly, was feeling lonely and did not feel like working; by contraries, would sit alone at some place or do drugs. Sometimes I felt rather angry. Sometimes, I would get involved in violence. Later on, it became a habit. Nowadays, it hardly makes a difference».

\section{References}

1. Boyden J, De BJ (2004 Children and Youth on the Frontline: Ethnography, Armed Conflict, and Displacement cited in: Pacione L, Measham T, Kronick R, Meloni R, Ricard Guay A, et al. (2015): The Mental Health of Children Facing Collective Adversity Poverty, Homeless. Oxford: New York, USA.

2. Werner EE (1982) Vulnerable, but invincible: A longitudinal study of resilient children and youth. American Journal of Orthopsychiatric Association 59.

3. Garmezy N (1991) Resilience in children's adaptation to negative life events and stressed environments. Pediatric Annals 20: 459-460, 463466.

4. Garmezy N (1991) Resiliency and vulnerability to adverse developmental outcomes associated with poverty. The American Behavioral Scientist 34(4): 416-430.
5. Luthar SS, Cicchetti D, Becker B (2000) The construct of resilience: A critical evaluation and guidelines for future work. Child Dev: 71: 543562.

6. Rutter M (2013) Annual research review: Resilience - clinical implications. J Child Psychol Psychiatry 54: 474-487.

7. DiCarlo MA, Gibbons J, Kaminsky D, Wright J, Stiles D (2000) Street Children's Drawings: windows into their life circumstances and aspirations. International Social Work 43(1).

8. Young L, Barrett H (2001) Adapting Visual Methods: action research with Kampala street children. Area 33(2): 141-152.

9. Orme J, Seipel, M.M. (2007). Survival Strategies of Street Children in Ghana: a qualitative study, International Social Work, 50(4): 489-499.

10. Ruiz-Casares M (2009). Between Adversity and Agency: Child and Youth-Headed Households in Namibia. Vulnerable Children and Youth Studies 4: 238-248.

11. Macalane JMalindi, Linda C Theron (2010) The Hidden Resilience of Street Youth. South African Journal of Psychology 40(3): 318-326.

12. Ayuku DO, Devries MW, Mengech H N, Kaplan CD (2004) Temperament characteristics of street and non-street children in Eldoret, Kenya. Afr Health Sci 4(1): 24-30.

13. Luna GC (1991) Street youth: Adaptation and survival in the AIDS decade. Journal of Adolescent Health 12: 511514.

14. Savarkar T (2018) Psychosocial Distress among Children Living on Street in Mumbai (Ph.D. dissertation) TISS database.

\section{Your next submission with Juniper Publishers will reach you the below assets}

- Quality Editorial service

- Swift Peer Review

- Reprints availability

- E-prints Service

- Manuscript Podcast for convenient understanding

- Global attainment for your research

- Manuscript accessibility in different formats ( Pdf, E-pub, Full Text, Audio)

- Unceasing customer service

Track the below URL for one-step submission https://juniperpublishers.com/online-submission.php 